\title{
The Farming Models Adapting to Climate Change in the Eastern Coastal Area of the Mekong River Delta, Vietnam
}

\author{
Nguyen Van Lap ${ }^{1, *}$, Lieu Kim Phuong ${ }^{1}$, Ta Thi Kim Oanh ${ }^{1}$, Ta Duy Thong ${ }^{2}$, Nguyen Thi Mong Lan ${ }^{1}$, \\ Vo Thi Hong Quyen ${ }^{1}$, La Tan Tai ${ }^{1}$ \\ ${ }^{1}$ Ho Chi Minh City Institute of Resources Geography, Vietnam Academy of Science and Technology, Ho Chi Minh City, Vietnam \\ ${ }^{2}$ Landscape Planning Laboratory, Graduate School of Horticulture, Chiba University, Matsudo City, Chiba, Japan
}

\section{Email address:}

nvlap@hcmig.vast.vn (N. V. Lap), lkphuong@hcmig.vast.vn (L. K. Phuong), ttkoanh@hcmig.vast.vn (Ta T. K. Oanh), Duythongta.tw@gmail.com (Ta D. Thong),ntmlan@hcmig.vast.vn (N. T. M. Lan), vthquyen@hcmig.vast.vn (VTH Quyen), tai.tanla1496@gmail.com (La T. Tai)

${ }^{*}$ Corresponding author

\section{To cite this article:}

Nguyen Van Lap, Lieu Kim Phuong, Ta Thi Kim Oanh, Ta Duy Thong, Nguyen Thi Mong Lan, Vo Thi Hong Quyen, La Tan Tai. The Farming Models Adapting to Climate Change in the Eastern Coastal Area of the Mekong River Delta, Vietnam. Ecology and Evolutionary Biology. Vol. 6, No. 1, 2021, pp. 1-7. doi: 10.11648/j.eeb.20210601.11

Received: November 28, 2020; Accepted: December 28, 2020; Published: January 4, 2021

\begin{abstract}
The Eastern coastal area of the Mekong River Delta has distinctly ecological zones and a potentiality for development of agriculture, forestry and fishery according to their ecological characteristics. The farmer life is mainly depending on exploiting agriculture, aquaculture and there are many supporting the development of social-economics in delta. However, the recent years, farming rice, vegetables, crops, fruit trees and raising shrimp, hard clam as well have heavily affected by drought and salt intrusion due to climate change. This has leaded to decrease the agricultural, fishery yield and the farmer's income, therefore, the farmer's life in the Eastern coastal area faces to the difficulties. The previous farming models are necessary to alter and this is a significant solution to minimize the risk and to cope the climate change such as farming system changes, to sustain agricultural production or transformation to alternative systems and combination between the rotational rice-shrimp-crops farming models following the season. Thus, the study proposes the farming models that can be suitable for the Eastern coastal locals of Mekong river delta. On the basis of document synthesis of natural characteristics, morpho-sedimentology, soil, vegatation cover, innundation, salinity, tidal water level indicating ecology and traditional farming, the study has given a general ecological model for the Eastern coastal area (Mekong Delta) to adapt to the climate change context. The general farming model including five models are clam farming, mangrove forest- shrimp farming, vegetables and fruit trees farming, rotational farming of rice, and rice- vegetables, and Rotation farming rice- shrimp, fruit- shrimp and fishes.
\end{abstract}

Keywords: Eastern Coastal Area, Mekong River Delta, Farming Model, Climate Change, Agriculture, Aquaculture

\section{Introduction}

The study area is extending from Tien Giang to Tra Vinh province in the Eastern coastal of Mekong River Delta (MRD) (Figure 1). This area belongs to the lower delta plain characterized by the rows of beach ridges trend northeast to southwest and are 2.5 to $8.0 \mathrm{~m}$ above mean sea level (amsl); they are separated by inter-ridge swamps that are about 1.5 to $2.5 \mathrm{~m}$ amsl. The modern, active subaerial delta environment is composed mainly of mangroves, beach ridges, and tidal flats. The coastal plain is about 1.0 to $2.0 \mathrm{~m} \mathrm{amsl}$, and marshes are scattered in its lower parts.

This area has two distinct seasons, the rainy season begins from May to the end of October and the sunny one is from November to April of the following year [1]. The high density of rivers, canals, tidal creeks is flowing through in the study area and pouring out the Eastern sea by estuaries: Tieu, Ba Lai, Co Chien, Cung Hau, etc. Together with the unequal semi-diurnal tide regime of the East Sea, an abundant alluvial volume provided from the Mekong river, the tidal flats of this area are typical of deltaic tidal flats [2]. The tidal regime in this area is a semi-irregular diurnal one of the East Sea with two flood tides and two ebb tides. Tidal amplitude changed 
from 2.9 to $3.4 \mathrm{~m}$. High tide amplitude is usually in November, December and January in the northeast monsoonal season with strong waves causing salinity intrusion inland and coastal erosion. The winter wave, from northeast to southwest, is dominant in December to February [3]. The winter current, from northeast to southwest, is dominant, and the summer current, from the opposite direction, is less intense. These major current patterns are induced by the monsoon. During January and February in the MRD, southwestward currents run strongest. The Eastern coastal area is generally less affected directly by the storm. Storms and tropical depressions, if present, are usually concentrated in October, November, and December with weak winds do not seriously affect to infrastructure, but significantly impact on clam grounds [2].

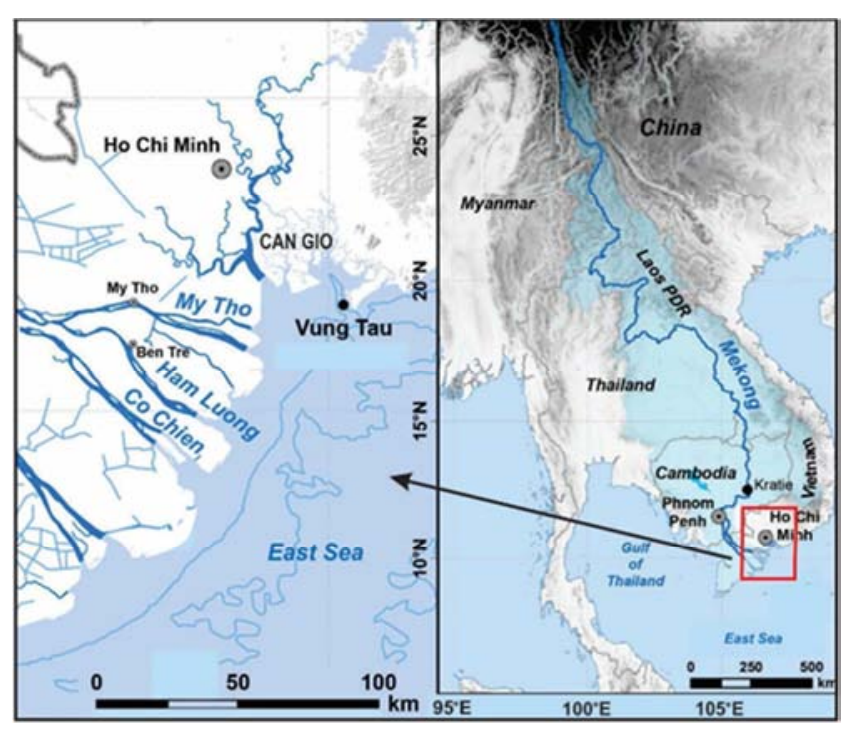

Figure 1. Location map of the Eastern Coastal area of MRD.

With the above natural features, the Eastern coastal area of MRD has lots of advantages and potentials in development of agriculture, forestry, fishery. Thus, the study reveals the farming models in which the famers are exploiting in the Eastern coastal area of MRD and propose the farming model adapting to climate change.

\section{Method}

Based on morpho- sedimentary map of the coastal area of MRD, field excursions were carried out to collect detailed data at the farming models in the sunny and rainy seasons as follows:

1. Collecting detailed topography, elevation of morpho-sedimentary units and grained size composition. Moreove, reclaimed lands such as roads, dykes, pools, ditches ... are also described.

2. Soil characteristics, and vegetation cover that are good indicators for land use,

3. Collecting tidal water level and salinity changes in dry and rainy seasons.

4. Land-use changes data.
5. Collecting annually statistical analysis, correlation collected data, and assessment of the advantages and disadvantages of the farming models;

6. Interview with questionnaire local farmers who realize the farming models from saline to fresh-brackish water ecologcial models such as clam in the sandy tidal flat, shrimp - mangrove to rice- shrimp in the freshbrackish water.

7. Integrating data, and prososing the farming models for adaptable to climate change and natural conditions in locals.

\section{Results and Discussion}

\subsection{Morpho-sedimentary Units of the Eastern Coastal Area of MRD}

On the base of geomorphological measures and litho-sedimentary analysis from cores bored in this area, the morpho-sedimentary units of this area are composed of beach ridges, inter-ridges, salt marsh, mangrove swamp, channel bar, abandonned channel, natural levee, and tidal flats (Figure 2) $[4]$.

\subsubsection{Beach Ridges}

Beach ridges are formed within or near the beach, and are preserved as relict elongate mounds parallel or subparallel to the shoreline following subsequent beach progradation. Beach ridges on the lower Mekong delta plain are convex seaward, and are associated with branching and recurved shapes, concordant with recent coastal changes. The beach ridges are generally $2.5-8.0 \mathrm{~m}$ above the present mean sea level (apmsl). The width of beach ridges is less than a few kilometers and shaped like a bow with high terrain forming long, narrow ridges that are easily distinguishable from the low lying mounds or marshes around [5]. The beach ridges are mainly composed of fine yellowish gray sand with a thickness of about 2.5-5.5 m, covered by sand, silty sand or silty clay tidal flat.

\subsubsection{Inter- Ridge}

Inter rigdes are characterized by low flat land and occupied between beach ridges system. They are mainly consisting of silt and sandy silt with the elevation of 1.5-2.0 $\mathrm{m}$ apmsl. In terms of geomorphology, the inter- ridges are inundated in the rainy season.

\subsubsection{Mangrove Swamp}

Mangrove swamp deposits occupy most of coastal lowland of the MDR. This is a low-lying terrain with an elevation of about 0.4 to $0.6 \mathrm{~m}$, with an interlacing tidal creek system, flooded during high tide and exposed at low tide. In coastal areas, mangrove swamp is distributed behind the tidal flats and/or present sand dunes, extending west and northwest. The mangrove swamp is composed mainly of dark gray to greenish gray silty clay, with a thickness of about 0.7 to 1.0 $\mathrm{m}$. Clay mangrove swamp deposit was exposed on the tidal flat where the coast was severely eroded. Recently, 
Rhizophora sp., Avicennia sp., Sonneratia sp., and Nippa fruticant are typical of coastal mangroves $[6,7]$.

\subsubsection{Tidal Flats}

Tidal flats are distributed in coastal areas, river mouths and are regularly inundated, just emerge when low tide. They extend from the supra-tidal zone through the inter-tidal zone and into the shallow portion of the sub-tidal zone. In eastern coast of the MRD, owing to semi-diurnal tide with amplitude of 3.0 - $3.8 \mathrm{~m}$, tidal flats mainly occupy a great width of 2.0 $5.0 \mathrm{~km}$ where sandy flats are dominant at the lower portion, but mixed flats at the upper one $[4,6]$. Depending on wave power, tide amplitude, coastal currents, and sediments provided from upstream, tidal flats will have different width and topography. Tidal flats are divided into sandflats and mudflats depending on the granular composition of the sediment [4].

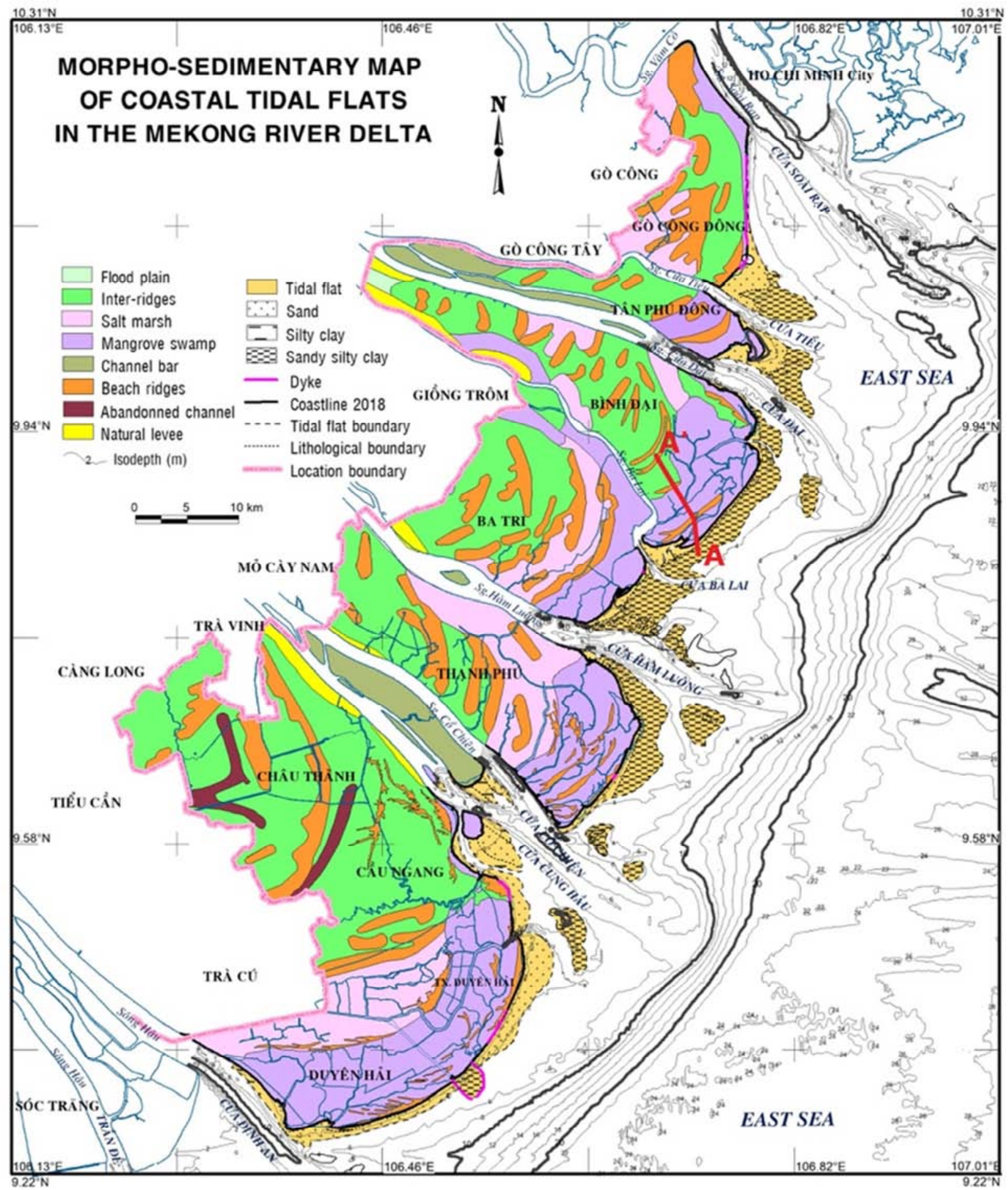

Figure 2. Morpho-sedimentary map of coastal tidal flats in the Mekong river delta [4]. 
Physical conditions such as wave height, tidal amplitudes and coastal currents in each area determine the sediment composition of the tidal flat as well as the height of the corresponding trough bar system. The sandflats are very popular in the high-energy coast, and mudflats often occur at low-energy coasts. The mudflat deposit contains much organic, so the mudflat is one of the most biologically productive wetland ecosystems.

Along the Eastern coastal area of Mekong river delta from Tien Giang to Tra Vinh, the characteristic of sedimentary geomorphology is tidal flat, beach ridge, mangrove swamp, and inter-ridge from sea towards the mainland and the variety of soil is such as salty soil, alkaline soil, alluvial soil, etc. The models are farming following of the natural conditions.

\subsection{Status of the Agricultural, Forestry and Fishery Models}

The study area is composed of a part of mainland along the Eastern coastal area of the MRD from Tien Giang to Tra Vinh province. The area includes three ecological zones: fresh, brackish and saline water. The agriculture, forestry and fishery models are exploiting as follows:

1. Model of farming clam on sandy tidal flat;

2. Model of farming vegetables, crops in rice growing area, farming rice-shrimp, rice-vegetables/crops;

3. Model of farming fruit tree;

4. Model of farming shrimp in mangrove swamp;

5. Model of farming organic vegetables, organic rice and ecological shrimp;

6. Model of farming applied technology shrimp.

However, the farming models have risked crop yield, shrimp died, etc because of the climate change effects. As a result of the yearly reports from three provinces, the farmers get hard problems in their life. The study has proposed models which achieved the high efficiency and good income for farmers as the following.

\subsection{The Typical Models of Study Area}

\subsubsection{Farming Clam on Sandy Tidal Flat}

The sandy tidal flat is widely spreading out Tien Giang Tra Vinh area and where is rich of saline sandy soils [7] and has the potential to develop farming clams. The sandy tidal flat in Duyen Hai, Tra Vinh province occupies larger than 6,000 hectares in which roughly 3,000 hectares have the suitable condition to farm clams (Owing to sedimentary supply, deposits occupy the sandy tidal flats thus the farming clam area has widened in Duyen Hai [8]. The farming clam attracts lots of labor sources in local and has a good income for farmers. Particularly, the framing clam in Ben Tre has certificated the first fishery area of Vietnam and Southeast Asia by Marine Stewardship Council since 2009 .

\subsubsection{Farming Shrimp in Mangrove Swamp}

Mangrove swamp is a low topography and saline water flooding around year and the abundant soil component of mangrove swamp is the saline soil [7]. The mangrove trees are habitat for shrimp, fish and provide food for aquatic species. Besides, the farmers have grown the mangrove trees in shrimp area to protect the eroded coastal sectors and the shrimp area. With this model, the farmers gain the high economic efficiency because of saving feeding for shrimp. Moreover, the farming shrimp in mangrove swamp is a way of forest protection and biodiversity conservation. In 2013, Tra Vinh province has 210 hectares of grown mangrove forest in the shrimp area. Most of mangrove forest plays buffer zone and has an important role in coverage and ecological rehabilitation [9].

\subsubsection{Farming Vegetables, Crops and Fruit Trees on Sandy Beach Ridge}

The sandy beach ridges are around 2.5-5.0 $\mathrm{m}$ apmsl indicating a higher topography than the inter-ridge and mangrove swamp surrounding area so it is rarely flooding. The high sandy beach ridge is proper to grow the vegetables/crops as radish, onions, peanut, sweet potatoes, etc and the fruit trees as water melon, longan tree, coconut tree, etc. These vegetables/crops and fruit trees are withstanding in drought and saline penetration due to affect of climate change. The models are progressing well principally, the organic vegetable model is appreciated and replicated in Tien Giang and Ben Tre on the sandy bar nearby the coastal area.

\subsubsection{Farming Rice - Shrimp or Rice - Vegetable in Inter- Ridge}

The inter - idge has the lower topography than the sandy beach ridge and the mainly soil component is the light salty and alkaline soils [7]. Inter rigdes are characterized by low flat land and occupied between beach ridges system. They are mainly consisting of silt and sandy silt with the elevation of 1.5- $2.0 \mathrm{~m}$ apmsl. Geomorphologically the inter- ridges are inundated in the rainy season so they are suitable to develop model of rotation farming rice/organic rice, shrimp and adapting to climate change. Rice has been grown in the rainy season from April or May to November and farming shrimp in the dry season from December to April in the following year. Rice yield gets worse as lack of fresh water and salty water intrusion. Hence, the rice-shrimp or rice-vegetables/crops rotational model is appreciated in alteration of fresh and saline water between the rainy and sunny season.

Adapting climate change, the models have altered in type of tree, seed, applied technology, farming time, etc. The typical model is suitable for natural conditions, morphosedimentology, soil features as shown in Figure 3. 


\begin{tabular}{c|c|c|c|c|c|c|c|} 
Model & $\begin{array}{c}\text { Vegetables/ } \\
\text { crops/ } \\
\text { fruits }\end{array}$ & $\begin{array}{c}\text { Rice-shrimp } \\
\text { rice- } \\
\text { vegetables }\end{array}$ & $\begin{array}{c}\text { Vegetables/ } \\
\text { crops/ } \\
\text { fruits }\end{array}$ & $\begin{array}{c}\text { Mangrove } \\
\text { forest- } \\
\text { shrimp }\end{array}$ & $\begin{array}{c}\text { Vegetables/ } \\
\text { crops/ } \\
\text { fruits }\end{array}$ & $\begin{array}{c}\text { Mangrove } \\
\text { forest- } \\
\text { shrimp }\end{array}$ & Clam \\
\hline $\begin{array}{c}\text { Soil } \\
\text { type }\end{array}$ & $\begin{array}{c}\text { Salty- } \\
\text { alkaline }\end{array}$ & Salty & $\begin{array}{c}\text { Salty- } \\
\text { alkaline }\end{array}$ & Salty & $\begin{array}{c}\text { Salty- } \\
\text { alkaline }\end{array}$ & $\begin{array}{c}\text { Saline } \\
\text { Soil }\end{array}$ & $\begin{array}{c}\text { Saline } \\
\text { Soil }\end{array}$ \\
\hline
\end{tabular}

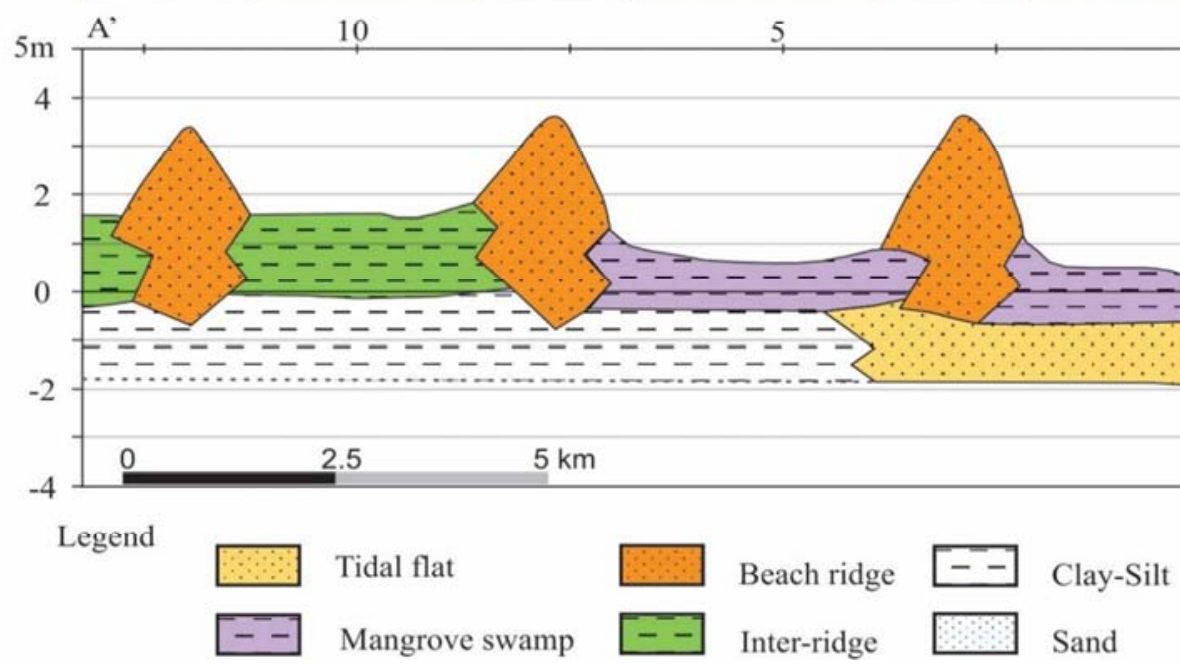

Figure 3. The typical farming model of the study area.

\subsection{The General Farming Model Adapting to Climate Change}

The Mekong Delta is one of the deltas strongly affected by climate change. According to the document "Climate change and sea level rise scenarios for Vietnam", by 2070-2080, the average sea level rise for the entire coastal areas of Vietnam under the RCP6.0 scenario is $60 \mathrm{~cm}$ [10]. Recently, saline water has penetrated into rivers earlier and deeper into the mainland than the previous years, the farming is lack of fresh water for irrigation of rice field, fruit tree, vegetables, crops, etc [11]. Particularly, the drought and saline water intrusion happened in the dry season of 2016 and 2020, the boundary of saline intrusion towards upstream is up to $55-110 \mathrm{~km}$ in the Mekong distributaries. In general, most of the crops have been significantly affected resulting to the farmer life gets worse and has a low income [12]. Because the farmers have not considered to effect of climate change in farming $[11,13]$. The below farming model is built based on the natural conditions, morpho- sedimentology and suitable for soils. It properly is sustainability, able to maintain in long-term and adapt to climate change (Figure 4).

The Eastern coastal side towards the mainland having the farming models as:

(1) Farming clam on sandy tidal flat.

The sand tidal flat is a flat plain consisting mainly of fine sand and affected by semi- diurnal tide with $3.0-3.4 \mathrm{~m}$ in range. The tidal flat is exposed for 2- 6 hours/day and 8-14 days/ month, however many surrounding mangroves give good facilities as environtment, foods ... to clam farming in the Eastern coast. Moreover, improving clam seed nursing for supplying to clam farming is realized with good results in Eastern coast [14]
(2) Farming shrimp or aquatic species and growing mangrove trees in mangrove swamp.

Mangrove swamps and salt marshes are well ocupied in the Eastern coast (Figure 2) and mainly composed of silt, clayey silt with organic materials. Mangroves characterized by Rhizophoracea, Avicenniacea, Sonneratiacea. Phoenix paludosa ... ocupy in the mangrove swamp with high- thick canopy cover, in contrary saline grasses are widespread in the salt marshed such as Eleocharis atropurpur, Paspalumu vaginatum, Scirpus littoralis ... to be low and sparse. Both mangrove swamp and salt marsh are very low topography, about $0-0.5 \mathrm{~m}$ apmsl, and characterized by $0-1.0 \mathrm{~m}$ tidal range; $5-15 \%$ salinity, so that it is suitable to cultivate shrimp and organic shrimp farmings. Owing to the coastal management of the local provinces, a protection forest zone is located along the coastline from that shrimp farming is done in 4:6 ratio of shrimp- forest in the rearward areas $[15,16]$.

(3) Farming the vegetables, crops or fruit trees on the top of sandy beach ridge; farming rice at the foot of sandy beach ridge.

Sandy beach ridge is almost high topography and composed mainly of fine sand, thus, it is not flooded, and do not effected by saline water and tidal range. Bambusoideae is presentative vegetation cover. In addition rainy water is a mainly supply source, so that it is suitable to grow farmings of vegetables, fruit trees [17].

(4) Rotational farming rice-shrimp, rice-vegetables/crops in inter-ridge.

Inter- ridge is medium topography, around $1.5-2.0 \mathrm{~m}$ apmsl. It is composed mainly of silt, sandy silt surrounding foot of sand beach rigde areas. Vegetation cover is characterized by Phragmites australis, Eleocharis dulcis. It is not effected by saline water and tidal range. It is suitable for 
rice and rice- vegetabe farmings.

(5) Rotation farming rice- shrimp, fruit trees- shrimp and fishes.

Channel bars of Mekong distributaries are characterized by big areas within 3.5- $5 \mathrm{~km}$ wide and 30- $35 \mathrm{~km}$ long (Figure 2 ), and mainly consisting of silt and clayey silt. The farmost upstream areas of these channel bars are approximately of 30 $\mathrm{km}$ lond from the coast, elevation about 1.5- $2.0 \mathrm{~m}$ apmsl and subjected by fresh water around 6 months in the rainy season and brackish water in the remainder. Vegetation cover is characterized by Nippa fruticans, Acanthus ebracteatus, Derris trifoliata indicating fresh to brackish water ecology, thus ditches are surrounding rice field with $5-6 \mathrm{~m}$ wide and 0.8-1.0 $\mathrm{m}$ deep (Figure 4). In the rainy season, freshwater occupies this area, thus rice cultivation has been started from September and harvasting in December. Since then shrimp farming is started due to $3-10 \%$ salinity. Moreover, crayfish, crab and fish are also interacted in rice cutivation.

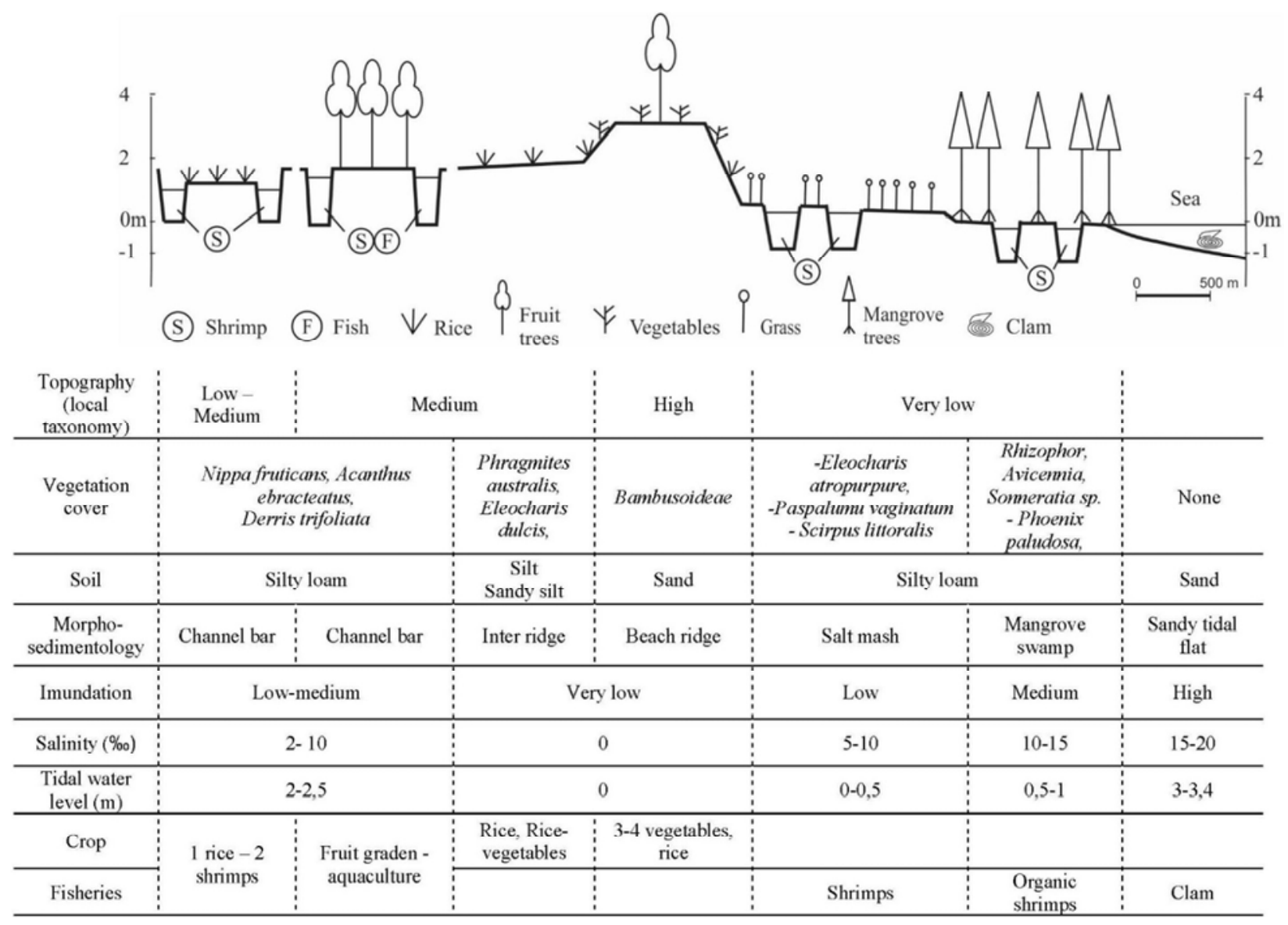

Figure 4. The general farming model of the Eastern Coast of the Mekong River Delta.

\section{Conclusion}

The Eastern coastal area is considered to be the most vulnerable to the impacts of climate change and the sea level rise in the MDR. This is considered as a key area specializing in saline and brackish water aquaculture. Therefore, the main livelihood strategy for coastal areas is to convert to fisheries towards sustainable development, adaptation to climate change, combined with coastal forest restoration.

In the face of climate change, many adaptive solutions have been implemented by farmers in the direction of changing in accordance with natural conditions and weather, helping to improve livelihoods, income and reduce risks. In the process of farming and coping with nature, many agricultural production models are formed based on the characteristics of land, topography, climatic conditions and people's experiences. Many integrated farming models have been converted from rice monoculture to more sustainable farming forms in the MRD such as rice - shrimp, rice - intercropped, rice vegetables, rice - fruit trees,... On the basis of document synthesis of natural characteristics, morpho-sedimentology, soil, vegatation cover, innundation, salinity, tidal water level indicating ecology and traditional farming, the study has given a general ecological model for the Eastern coastal area (Mekong Delta) to adapt to the climate change context. The general farming model including five models are clam farming, mangrove forest- shrimp farming, vegetables and fruit trees farming, rotational farming of rice, and ricevegetables, and Rotation farming rice- shrimp, fruit- shrimp and fishes.

These are models of shifting farming that are biased, towards sustainability, maintaining ecosystems and 
effectively responding to changes to climate change. In particular, people in the coastal area also have creative farming models that adapt to climate change, forming many diverse agricultural models. The diversity of models shows high dynamism and adaptability of the people.

The farming model is highly appreciated and suitable for climate change as evidenced the risk of crop yield is low in 2020. Moreover, the model has developed and the increased mangrove swamp area along the Eastern coastal of MRD to limit the erosion of the coastal line and environmental protection. The farmer gains the high income and the life farmer is increasing.

\section{Acknowledgements}

We sincerely thank MOST grant from Vietnam (Grant Number KC.09.35/16-20) for funding and facilitating the implementation of the project.

\section{References}

[1] Statistical yearbook of Tien Giang, Ben Tre and Tra Vinh provinces, Vietnam. Statistical Publishing House. 2018 and 2019, 428 p.

[2] Ta Thi Kim Oanh, et al. Overall assessment on natural, environmental conditions for mollusk exploitation and aquaculture (Meretrix lyrata, Anadara granosa) to develop economy of coastal areas of Tra Vinh province. Project final report - VAST. 2012, 39 p. (in Vietnamese).

[3] Vietnam Hydro-meteorological Atlas. International Hydrological Program, Vietnam National Committee, 1994, 67 p.

[4] Nguyen Van Lap, et al. Study on formation and forecast the variation tendency of coastal estuarine tidal flats from Tien Giang to $\mathrm{Ca} \mathrm{Mau}$ in the Mekong delta and propose solutions for exploitation for socio-economic development. Project final report - VAST. 2020, 25 pages (in Vietnamese).

[5] Nguyen Van Lap and Ta Thi Kim Oanh. Sedimentary characteristics of sand dunes in Cau Ngang and Tra $\mathrm{Cu}$ Districts, Tra Vinh province and their freshwater - bearing capacity. Vietnam Journal of Earth Sciences. 2014, 36 (2), p. 131-138 (in Vietnamese).

[6] V. L. Nguyen, T. K. O. Ta, M. Tateishi. Late Holocene depositional environments and coastal evolution of the Mekong River Delta, Southern Vietnam, Journal of Asian Earth Sciences. 2000, 18, p. 427-439.

[7] Sub-Institute of Agricultural Planning and Design, Ministry of Agriculture and Rural Development, 2004. Project of Investigation, Supplementation, Edition, and Development of Land Mapping in Mekong Delta Provinces. 2004 (in Vietnamese).

[8] Ta TKO, Nguyen VL, Nguyen TML, Ta DT, Vo THQ. Natural and environmental characteristics of Tra vinh province coastal areas, Mekong Delta, Vietnam for the development of hard clam culture. Journal of Biodiversity and Environmental Sciences. 2018, 11-20.

[9] Bui TN. Model of shrimp-mangrove forest in the Mekong Delta. Can Tho univ., Journal of Science and Technology, 2011, 12. 48-50 (in Vietnamese).

[10] Ministry of Natural Resources and Environment, Climate change and sea level rise scenarios for Vietnam, 2016, 187 p.

[11] Carew-Reid. Rapid assessment of the extent and impact of sea level rise in Vietnam. ICEM, Brisbane, 2008, 82.

[12] Tran TB. Le CD and Brennan, D. Envorinmental cost of shrimp culture in the ricegrowing regions of the Mekong delta, Aquaculture Economics and Management 3 (1) 31-42.

[13] Nhan D. K., Trung, N. H., Van Sanh, N. The impact of weather variability on rice and aquaculture production in the Mekong Delta. In M. A. Stewart \& P. A. Coclanis (Eds.), Environmental Change and Agricultural Sustainability in the Mekong Delta (pp. 437-451): Springer. 2011.

[14] Ta TKO, Nguyen VL, Nguyen TML, Ta DT, Improving Model of Hard Clam (Meretrix lyrata) Seed Nursing in the Coastal Area - Case Study in Tra Vinh Province, Mekong River Delta, Vietnam. Ecology and Evolutionary Biology, 2020, 5/4, 182-188.

[15] Bui TN, Le DH. Model of organic shrimp in the coastal area of Mekong Delta. Can Tho univ., Journal of Sci., 2015, 3/53, 14-17 (in Vietnamese).

[16] Nguyen T, Tran TKT, Nguyen THC. Shrimp Yield in Relation to the Ecological Parameters of an Organic Shrimp Model in the Mekong Delta of Vietnam: A Case Study. Asian Fisheries Science, 2019, 32, 154-161.

[17] Le A. T, Hoang TT, Vo VN. Cropping models to respond climate change for coastal sand dunes in the Mekong Delta, Can Tho univ., Journal of Sci., Topics: Environment and climate Changes, 2015, 150-158 (in Vietnamese). 